\title{
LIVRO DIDÁTICO: TRÊS PROPOSTAS PARA SE TRABALHAR COM TEXTOS
}

\author{
DIDATIC BOOK: THREE PROPOSALS FOR WORKING \\ WITH TEXT
}

\author{
Karen Neves Olivan ${ }^{1}$ \\ Mestranda do Programa de Pós-graduação em Linguística - UFSC
}

\begin{abstract}
Resumo
Este trabalho traz uma análise das metodologias de ensino presentes em três livros didáticos da $5^{\mathrm{a}}$ série $\left(6^{\circ}\right.$ ano) do Ensino Fundamental, observando se a seleção e a organização dos conteúdos estão de acordo com os eixos norteadores dos Parâmetros Curriculares Nacionais de Língua Portuguesa. Como objeto de análise, são observadas as propostas de atividades textuais, tendo como aporte teórico a teoria de gêneros textuais. O trabalho é composto de duas partes de análise destinadas à abordagem textual, iniciando pelos pressupostos teóricos da Linguística Textual e, em sequência, a análise das atividades propostas nos livros didáticos. Ao fim dos estudos, promove-se uma reflexão sobre a importância da escolha do livro didático, considerando a linha de trabalho adotada pela escola e pelo professor, bem como o público envolvido nesta relação pedagógica.
\end{abstract}

Palavras-chave: Livro didático. Texto. Gênero textual.

\begin{abstract}
This work presents an analysis on the teaching methodologies from three didactic books from the 5th grade (current 6th grade) in elementary school, observing if the selection and organization of the subjects are according to the National Curricular Parameters of the Portuguese Language. As the aim of the analysis, textual activities proposals were observed, based on the textual genre theory. The work is made up of two parts of analyses destined to the textual approach, starting with the theoretical assumptions of the Textual Linguistics and, on the sequence, the analysis of the activities proposed on the book. By the end of the study, a reflection on the importance of the choosing of the didactic book is promoted, considering the methodology chosen by the school and the teacher, as well as the public involved in this pedagogic relationship. Besides, the didactic books which were analyzed go along with this work.
\end{abstract}

Keywords: Didactic books. Text. Textual genre.

\section{INTRODUÇÃO}

Observando, no ambiente acadêmico e profissional, o depoimento de vários professores, percebe-se que o ensino de Língua Portuguesa não atinge o objetivo esperado, que é o

\footnotetext{
${ }^{1}$ Além de Mestranda em Linguística pela Universidade Federal de Santa Catarina (UFSC), é Pósgraduanda em Estudos Linguísticos e Literários Aplicados ao Ensino pela Universidade do Sul de Santa Catarina (UNISUL) e Professora da rede particular de ensino em Santa Catarina.
} 
desenvolvimento da competência textual do aluno tanto para a produção quanto para a recepção. Fato esse que denuncia o descumprimento do proposto pelo PCN - Parâmetro Curricular Nacional - de Língua Portuguesa, o qual defende que o ensino da língua deve ter um enfoque enunciativo ou semântico, a fim de desenvolver as competências linguísticas do aluno.

Segundo o PCN de Língua Portuguesa (BRASIL, 1997, p. 35), para desenvolver as habilidades linguísticas básicas, os conteúdos devem ser selecionados e organizados em torno de dois eixos norteadores: “[...] o uso da língua oral e escrita e a análise e reflexão sobre a língua”.

Além disso, ainda de acordo com o PCN de Língua Portuguesa (BRASIL, 1997, p. 37), "[...] determinados objetivos só podem ser conquistados se os conteúdos tiverem tratamento didático específico [...]”, tratamento esse que é verificado através do instrumento mais presente na sala de aula: o livro didático.

Por essa razão, delimitou-se como tema deste artigo a verificação das atividades propostas em três livros didáticos do $6^{\circ}$ ano do Ensino Fundamental, observando a metodologia utilizada e se as mesmas levam o aluno à reflexão sobre os aspectos da língua.

Sabe-se, no entanto, que, desde 1997, ano de publicação dos PCNs, o livro didático vem sofrendo periódicas reformulações a fim de se adaptar melhor ao proposto por aqueles, isto é, almeja-se um enfoque não apenas na gramática tradicional, a qual está voltada quase que exclusivamente para as classificações morfológica e sintática, mas sim um trabalho que examine de que forma a língua é usada nas mais diversas dimensões fonética, morfossintática, semântica, estilística - para a construção do sentido do texto.

Sendo assim, este artigo se propõe a analisar quais das atividades propostas nesses três livros didáticos vão ao encontro do trabalho idealizado pelo PCN de Língua Portuguesa (BRASIL, 1997, p. 36), ou seja, apresentam-se “[...] em função do eixo USO $\rightarrow$ REFLEXÃO $\rightarrow$ USO.”, o qual indica que o professor deve focalizar seu trabalho na Prática de leitura, na Prática de produção de texto e na Análise e reflexão sobre a língua.

Constituem-se como objeto de análise neste artigo três livros didáticos do $6^{\circ}$ ano do Ensino Fundamental, desenvolvidos de acordo com os Parâmetros Curriculares Nacionais (PCNs), para serem trabalhados na disciplina Língua Portuguesa. São eles:

Linguagem, criação e interação, de Cassia Leslie Garcia de Souza e Marcia Paganini Cavéquia, da editora Saraiva, o qual foi adotado por um número significativo de escolas da rede oficial (pública e privada) de Educação Básica, no Ensino Fundamental, nos Estados de Santa Catarina e Paraná, no ano de 2007.

Português: dialogando com textos, de Beatriz Marcondes e Paula Parisi, da editora Formato, o qual tem sido adotado por escolas que pretendem justificar a necessidade de um redirecionamento das aulas de Língua Portuguesa, focando o aprendizado da estrutura gramatical. 
Língua Portuguesa, de Juliana Villa-Bôas e Pedro Faria Borges, do IBEP - Instituto Brasileiro de Edições Pedagógicas -, órgão responsável pela aprovação dos livros didáticos a serem adotados na rede pública municipal e estadual. Livro este que está em sua primeira edição e que fora encomendado às autoras, que realizam este tipo de trabalho pela primeira vez, com a finalidade de produzirem um material adequado ao PCN de Língua Portuguesa.

Cabe esclarecer que a seleção do material aqui feita é apenas um recorte para análise. Isso significa que as conclusões aqui apresentadas podem ou não ser adequadas a outros livros, e, consequentemente, uma análise com outros recortes acrescentaria novas conclusões.

Por fim, este artigo está dividido em duas partes de análise, com as seguintes finalidades:

A primeira parte traz um breve histórico da linguística textual, para que se localize e entenda o período em que nos encontramos; aborda os conceitos de discurso, texto e gêneros textuais e discute sobre os elementos fundamentais à construção de sentidos do texto: coesão, coerência, intertextualidade e polifonia. Na parte segunda, faz-se a análise do trabalho proposto nos três livros didáticos acerca do texto. Nas considerações finais, discute-se a importância das propostas de atividades textuais a partir de gêneros discursivos e das atividades gramaticais por meio de uma metodologia reflexiva.

\section{SOBRE O TEXTO}

Como o objetivo deste artigo, conforme apresentado na introdução, é a análise de livros didáticos de Língua Portuguesa e sendo estes organizados em unidades ou capítulos que propõem, além de outras atividades, as práticas de leitura e produção textual, faz-se necessária uma breve explanação sobre os estudos referentes ao texto, incluindo o percurso histórico da linguística textual, as definições de texto e as concepções que envolvem esta temática, como discurso, gêneros textuais, intertextualidade e polifonia.

\subsection{O que a história tem nos dito sobre o texto?}

Atualmente, constitui-se uma necessidade real tomar o texto como unidade de análise ao se ingressar no campo de estudos da linguagem.

Marcuschi e Koch (1998) enumeraram estudos de vários autores ${ }^{2}$ que constituíram a primeira geração a qual propôs o texto como unidade legítima dos estudos linguísticos, dando, assim, uma guinada nos estudos da língua.

Segundo Bentes (2001), a constituição do campo da Linguística de Texto deu-se, historicamente, em vários países de forma independente, simultânea e com propostas

\footnotetext{
2 “[...] P. Hartman (1964), R. Harweg (1968), E. Gulich (1968), W. Koch (1971), H. Weinreich (1964, 1976), J. Petöfi (1968), na Alemanha; Van Dijk (1972), na Holanda; Firth (1957) e Halliday e Hassan (1973, 1976), na Inglaterra; Mathesius (1961), Firbas (1971) e Danes (1970), em Praga; Z. Harris (1952) e K. Pike (1967), nos Estados Unidos.” (BENTES, 2001)
} 
teóricas diversas. No entanto, há três momentos que abrangeram preocupações teóricas bastante distintas entre si e que não só reforçam a ampliação do objetivo da análise da Linguística Textual, como também se afastam da influência teórico-metodológica da Linguística Estrutural saussureana.

Em um primeiro momento, o interesse voltava-se para a análise transfrástica, cujo foco eram as relações estabelecidas entre as frases e os períodos, a fim de se construir uma unidade de sentido, isto é, tratava-se de uma análise para fenômenos que teorias sintáticas e/ou semânticas limitadas ao nível da frase não conseguissem explicar, como, por exemplo, o fenômeno da co-referenciação, o qual só poderia ser bem compreendido no interior do texto. Em um segundo momento, postulou-se a descrição da competência textual do falante, através da gramática gerativa. No terceiro momento, segundo Bentes (2001, p. 247), “[...] o texto passa a ser estudado dentro de seu contexto de produção e a ser compreendido não como um produto acabado, mas como um processo, resultado de operações comunicativas e processos lingüísticos em situações sociocomunicativas”.

Cabe esclarecer que, no primeiro momento da Linguística Textual, havia dois conceitos de texto bastante relevantes. Texto, para Harweg (apud BENTES, 2001, p. 247), era “[...] uma seqüência pronominal ininterrupta [...]”, cuja principal característica era o fenômeno do múltiplo referenciamento, isto é, quando aquilo sobre o que se fala é retomado de diferentes maneiras no decorrer do texto. Já, para Isenberg (apud BENTES, 2001, p. 247), era uma “[...] seqüência coerente de enunciados [...]”, que seria o resultado de uma produção discursiva, levando-se em conta o contexto em que esta ocorre.

De acordo com Marcuschi (2003), quando as primeiras gramáticas textuais foram elaboradas, o texto era visto como um sistema uniforme, em oposição ao discurso, isto porque a proposta de elaboração de tais gramáticas objetivava refletir sobre os fenômenos linguísticos inexplicáveis através de uma gramática do enunciado. Naquela época, o texto era considerado a unidade linguística que conduzia, por meio de segmentação, a unidades menores a serem classificadas. Entretanto, a segmentação e a classificação deveriam considerar, sempre, a função textual dos elementos individuais. Por fim, segundo Travaglia (2002), todo falante nativo possui três capacidades textuais básicas: a) capacidade formativa, que possibilita aos usuários da língua a produção e a compreensão de um número de textos ilimitado, bem como a avaliação destes quanto à formação; b) capacidade transformativa, que possibilita aos usuários da língua a modificação de um texto, bem como o julgamento destas modificações quanto à adequação; c) capacidade qualificativa, que possibilita aos usuários da língua o esclarecimento da tipologia de dado texto.

Segundo Fávero e Koch (1983), uma vez dotados de tais habilidades, pode-se afirmar que os usuários da língua possuem competência textual - conjunto de regras internalizadas pelo falante -, o que justificaria a elaboração de uma gramática textual. Proposta essa que foi bastante influenciada pela perspectiva gerativista.

Apesar de importante essa proposta, não era possível executar as tarefas enumeradas a contento, pois o modelo teórico construído não garantia um tratamento homogêneo dos fenômenos pesquisados. Logo, os estudiosos trataram de elaborar uma teoria do texto, a 
qual se propunha, de acordo com Bentes (2001, p. 251), “[...] a investigar a constituição, o funcionamento, a produção e a compreensão dos textos em uso".

Foi, então, no terceiro momento, conforme Bentes (2001, p. 252), que os textos passaram a ser tratados em seu contexto pragmático e que as mudanças as quais aconteceram em relação às concepções da língua, às concepções de texto e em relação aos objetivos a serem alcançados, transformaram a Linguística de Texto em uma disciplina interdisciplinar, "[...] em função das diferentes perspectivas que abrange e dos interesses que a movem.”

\subsection{Texto}

Segundo Koch (2000), é relevante entender que diversos fenômenos linguísticos só são possíveis de serem explicados no interior do texto e como o homem, por natureza, comunica-se através de textos, torna-se necessária a compreensão de suas mudanças conceituais ao longo dos períodos supracitados.

Nos períodos da análise transfrástica e da elaboração de gramáticas textuais, os conceitos de texto, segundo Koch (2000), iam desde "[...] unidade lingüística superior à frase [...]" até “[...] complexo de proposições semânticas [...]”, mas a concepção mais utilizada fora feita por Stammerjohann (apud BENTES, 2001, p. 253):

O termo texto abrange tanto textos orais, como textos escritos que tenham como extensão mínima dois signos lingüísticos, um dos quais, porém, pode ser suprido pela situação, no caso de textos de uma só palavra, como "Socorro!", sendo sua extensão máxima indeterminada.

Na segunda fase da linguística textual, que abarca a elaboração de uma teoria de texto, segundo Bentes (2001, p. 254), a definição de texto deveria levar em conta uma das três atividades: atividade verbal, que se dá quando o emissor produz um enunciado, o qual irá produzir no receptor determinado efeito, ainda que não seja aquele que o emissor almejava; atividade verbal consciente, isto é, intencional; atividade interacional, em que os interlocutores estão envolvidos no processo de construção e compreensão de um texto.

Já, na terceira fase, essas três atividades devem ser associadas, e isso é condição fundamental para se definir o texto como texto. É nessa fase, atual, que se encontra o conceito de texto utilizado como base neste estudo. Conforme Beaugrande (apud $\mathrm{KOCH}, 2006$, p. 20), texto é um:

[...] evento comunicativo no qual convergem ações lingüísticas, cognitivas e sociais. Trata-se, necessariamente, de um evento dialógico (Bakhtin), de interação entre sujeitos sociais contemporâneos ou não, co-presentes ou não, do mesmo grupo social ou não, mas em diálogo constante. 


\subsection{Relação discurso/texto}

Como a comunicação se dá por meio de textos, desenvolver a competência comunicativa é desenvolver a capacidade de produção e de compreensão de textos nas diversas situações discursivas de enunciação.

Segundo Travaglia (2002), discurso é toda atividade comunicativa que engloba não só os enunciados produzidos, mas também o evento de sua enunciação. Assim, pode-se dizer que este, além de trazer informações, produz efeitos de sentido, diretamente relacionados com a intenção comunicativa e, consequentemente, com a função dos elementos linguísticos. Além disso, o processo de significação e o uso dos elementos linguísticos mantêm uma forte inter-relação com o sócio-histórico e o ideológico.

De acordo com a teoria do discurso, ao usarmos a língua para nos comunicarmos, promovemos uma interação, pois se trata de uma ação de mão dupla, ou seja, que atua tanto sobre o emissor quanto sobre o receptor do texto. Observamos, então, que cada enunciado depende do evento de sua enunciação.

Cabe esclarecer que enunciado é uma palavra, ou uma sequência delas, produzidas pelo emissor, ou seja, conforme Brandão (1996, p. 90), "[..] é a figura da enunciação que representa a pessoa cujo ponto de vista é apresentado”. Enquanto que, enunciação, segundo Guimarães (apud TRAVAGLIA, 2002, p. 71), é entendida como “[...] o acontecimento sócio-histórico da produção do enunciado". Logo se entende que a enunciação é responsável pela produção de efeito de sentido que, por ser intrínseco ao contexto, nunca se repete.

Portanto, os elementos linguísticos escolhidos por um produtor de texto, assim como as informações por ele selecionadas e o modo como ele as organiza, depende do que Travaglia (2002) chama de condições de produção, isto é, do que se costuma chamar de contexto.

\subsection{Gêneros textuais}

Conforme Bahktin (apud KOCH, 2006, p. 53), todas as atividades humanas estão relacionadas ao uso da língua, logo "Não é de surpreender que o caráter e os modos dessa utilização sejam tão variados como as próprias esferas da atividade humana [...]”. Sendo assim, pode-se afirmar que todos os enunciados baseiam-se em formas-padrão, isto é, em gêneros, pois esses enunciados estão diretamente relacionados às diversas situações sociais.

A competência sociocomunicativa dos falantes/ouvintes habilita-os à seleção do que é adequado ou inadequado às práticas sociais e, consequentemente, instrumentaliza-os para a diferenciação dos gêneros textuais. Essa competência permite ainda que se faça a distinção das modalidades retóricas, as quais, segundo Meurer (2000), são estratégias de organização da linguagem (funções narrativas, descritivas, expositivas ou argumentativas). 
Os gêneros são, assim como as esferas de utilização da língua, heterogêneos, por isso, Bakhtin (apud KOCH, 2006, p. 54) diferencia os gêneros primários dos secundários.

Enquanto os primeiros (diálogo, carta, situações de interação face a face) são constituídos em situações de comunicação ligadas a esferas sociais cotidianas de relação humana, os segundos são relacionados a outras esferas, públicas e mais complexas, de interação social, muitas vezes mediadas pela escrita e apresentando uma forma composicional monologizada $[\ldots]$

Então, segundo Koch (2006, p. 55), em termos bakhtinianos, um gênero pode ser caracterizado por possuir uma forma de composição própria, por distinguir-se pelo conteúdo temático e pelo estilo e por conter a vontade enunciativa do locutor. Portanto, a escolha do gênero a ser utilizado em determinada construção textual deve "[...] levar em conta os objetivos visados, o lugar social e os papéis dos participantes.”, ou seja, deve considerar a textualidade.

Entende-se por textualidade o fenômeno linguístico constituído a partir da coerência e da coesão presentes nos textos veiculados nas práticas sociais em que se encontram inseridos, sendo que, para Koch (2000), a coerência é o resultado extraído pelos interlocutores de dada construção textual. Portanto, pode-se afirmar que a coerência interna constrói-se a partir do texto, e, para que ela atinja os objetivos do locutor, os recursos coesivos são de suma importância, pois fornecem pistas para a construção de sentidos por parte dos locutários.

Logo, cabe esclarecer que, segundo Koch (2000), o conceito de coesão associa-se à maneira como os elementos linguísticos existentes na superfície textual são interligados, de modo que formem sequências veiculadoras de sentidos. Coesão essa que se subdivide em duas grandes modalidades: a remissão e a sequenciação.

A coesão por remissão pode exercer, conforme Koch (2000, p. 32) “[...] quer a função de (re)ativação de referentes, quer a de ‘sinalização' textual’.

A função de reativação de referentes é realizada ou pela referenciação anafórica, aquela cuja referência está ligada a um termo antecedente, ou pela catafórica, aquela cuja referência está ligada a um termo mais adiante. Remissão essa que pode ser realizada através de recursos gramaticais (pronomes, numerais, advérbios pronominais, artigos definidos), de recursos de natureza lexical (sinônimos, hiperônimos, nomes genéricos, descrições definidas), por reiteração de um mesmo grupo nominal ou por elipse. Frequentemente, essa referenciação dá-se via inferenciação.

A função de sinalização textual, ou dêixis textual ${ }^{3}$, é organizar o texto, dando apoio ao interlocutor para que este faça o processamento textual idealizado.

A coesão de um texto não é resultado do acaso, mas das relações de sentido que existem entre eles, logo o uso adequado dos elementos de coesão dá unidade ao texto,

\footnotetext{
${ }^{3}$ Koch julga mais adequado falar dêixis textual do que 'sinalização textual', para referir-se à 'mostração' dêitica no interior do próprio texto. (KOCH, 2000).
} 
contribuindo para a clareza de idéias. Clareza essa que é fundamental à adequação de cada texto a seu contexto.

Objetivando capacitar os alunos ante a recepção e produção de textos, tem-se, segundo o PCN de Língua Portuguesa, pensado o ensino da produção de texto a partir do enfoque de gêneros.

De acordo com Schneuwly e Dolz (apud KOCH, 2006), os gêneros textuais, cada qual com o seu fim social, tornam-se meio de articulação entre as práticas sociais e os objetos escolares, principalmente como recurso ao trabalho da produção e compreensão de textos, sejam estes escritos ou orais.

Percebe-se, então, que, na escola, ocorre um desdobramento dos gêneros, pois eles são estudados completamente isolados de suas respectivas situações de comunicação, apesar de a escola ser um lugar ideal para se trabalhar a comunicação, devido à multiplicidade de gêneros passíveis de circulação nela.

Por fim, Koch (2006) expõe que o trabalho com gênero na escola é fruto de escolhas didáticas com objetivos precisos de aprendizagem, ou seja, levar o aluno a dominar o gênero, através da apresentação, compreensão e produção deste, expondo-o, simultaneamente, a situações de comunicação o mais próximo possível da realidade.

\subsection{Intertextualidade e polifonia}

Para haver discurso é preciso haver sobreposição de vozes, pois não existe discurso inocente, mas sim, uma reconstrução que é feita com base em um posicionamento sobre algo já dito. Deste modo, Pêcheux (apud KOCH, 2000, p. 47) afirma que "[...] dado discurso envia a outro, frente ao qual é uma resposta direta ou indireta, ou do qual ele 'orquestra' os termos principais, ou cujos argumentos destrói. Assim [...] o discurso se estabelece sempre sobre um discurso prévio [...]”.

Entende-se, então, que todo discurso está inserido em certo universo de textos mediadores que oferecem esclarecimentos fundamentais. Trata-se, conforme Verón (apud KOCH, 2000, p. 47), “[...] de uma intertextualidade 'profunda', por se tratar de textos que, participando do processo de produção de outros textos, não atingem nunca [...] a consumação social dos discursos”.

De acordo com Koch (2000), há ainda a intertextualidade em sentido restrito, a qual mostra a relação de um texto com outros textos prévia e efetivamente produzidos. Esta pode ser de conteúdo, quando um autor imita ou parodia determinado escritor; explícita, quando se cita a fonte utilizada; implícita, quando não se expressa a fonte, mas se recorre a ela a fim de construir o sentido do texto; de semelhanças, quando o texto segue a orientação argumentativa do intertexto; de diferenças, quando o texto incorpora o intertexto para ridicularizá-lo, e intertextualidade com o intertexto alheio, quando as enunciações são parte de um repertório de uma comunidade.

Portanto fica claro que na intertextualidade a qualidade que é do outro é atestada pelo intertexto, o que nem sempre acontece na polifonia, pois, nesta, basta que a qualidade 
do outro seja encenada, ou seja, dá-se ao texto diferentes perspectivas, opiniões, com as quais o locutor pode ou não se identificar. Sendo assim, pode-se afirmar que toda intertextualidade é polifonia, mas nem toda polifonia é intertextualidade.

Logo, sob o prisma da construção de sentidos, esclarece-se que todo o texto é polifônico, pois ele é, conforme Koch (2000, p. 57), “perpassado por vozes de diferentes enunciadores, ora concordantes, ora dissonantes, o que faz com que se caracterize a linguagem humana”.

\section{MATERIAL DIDÁTICO: DESENVOLVENDO A COMPETÊNCIA TEXTUAL?}

Esta parte tem por objetivo a descrição e a análise do material já definido na introdução deste artigo, observando como as atividades textuais, sejam elas de leitura, interpretação ou escrita, são organizadas nas unidades que compõem o livro didático.

Devido ao tratamento uniforme que se observou por parte dos autores quanto à abordagem das questões textuais, a análise se estabelece a partir da descrição da primeira unidade, a qual pode ser tomada como parâmetro para as demais.

\subsection{Confundindo: Linguagem: criação e interação}

O livro Linguagem: criação e interação apresenta-se dividido em dez unidades, organizadas internamente de modo uniforme e subdivididas nas seções: Abertura, Momento do texto 1, Painel do texto, Estudo do texto, Ampliação do vocabulário, Momento do texto 2, Estudo do texto, Produção oral, Questões textuais, Produção escrita e Estudo da língua.

Objetivando ampliar a visão dos alunos em relação às questões textuais, as autoras trazem a seção Abertura (SOUZA; CAVÉQUIA, 2005, p. 13), em que podemos observar, já na primeira unidade deste, a apresentação de um texto não-verbal - a tela "o bibliotecário”, de Giussepe Arcimboldo -, a fim de iniciar uma discussão sobre os efeitos de sentido por ele provocados. Desse modo, podemos considerar que, para as autoras, o conceito de texto extrapola o limite do texto verbal, em consonância ao exposto em Travaglia (2002, p. 67):

O texto será entendido como uma unidade lingüística concreta (perceptível pela visão ou audição), que é tomada pelos usuários da língua (falante, escritor/ouvinte, leitor), em uma situação de interação comunicativa específica, como uma unidade de sentido [...]

No decorrer da unidade, as autoras trazem textos variados, tanto em linguagem verbal quanto não-verbal e mista, promovendo, além das atividades com foco na interpretação destes, uma discussão acerca de gêneros textuais, afinal, segundo Meurer (2000), aprender a língua materna é desenvolver a competência no uso de um número de gêneros textuais, entendendo que estes possuem características funcionais e organizacionais adequadas aos contextos em que são utilizados. 
Ainda em relação a este trabalho, as autoras explicitam que cada texto possui suas próprias características e, por isso, correspondem a diferentes gêneros. Distinção essa que, segundo Meurer (2000, p. 149), é essencial, pois se trata de uma competência que "[...] engloba igualmente a capacidade de uma competência de compreender de maneira [...] crescente as práticas discursivas e as relações sociais associadas ao uso de diferentes gêneros”.

Depois, propõem o trabalho com as produções oral e escrita. Na produção oral, de acordo com o caderno Orientações ao professor (SOUZA; CAVÉQUIA, 2005, p. 8), o objetivo é levar o aluno a "[...] refletir sobre os aspectos próprios dessa modalidade da língua, sobre as características de certos gêneros orais [...]”. E a produção escrita tem como finalidade tornar os alunos competentes produtores de texto, a partir da reflexão sobre três pontos básicos: o autor, o destinatário e o objetivo.

Percebemos que a articulação que as autoras fazem com a atividade pré-texto, as atividades de leitura e compreensão e o estudo da língua, que conceitua a linguagem verbal, não-verbal e mista, é bastante interessante, visto que propõem o estudo do texto a partir de seu contexto de produção, ou seja, que este, assim como Bentes (2001, p. 247), não deve ser compreendido "[...] como um produto acabado, mas como um processo, resultado de operações comunicativas e processos lingüísticos em situações sociocomunicativas”.

No entanto, essa articulação não se apresenta em uma sequência contínua, pois atividades com focos diferentes são inseridas entre as abordagens textuais, rompendo o objetivo geral da unidade. Por exemplo, na página 14, na seção Momento do texto 1, o livro traz uma História em Quadrinhos, elaborada em linguagem não-verbal, de Eva Furnari, por se tratar, segundo o caderno Orientações ao professor (SOUZA; CAVÉQUIA, 2005, p. 32), de “[...] um gênero textual familiar à maioria dos alunos e cuja leitura costuma ser bastante aprazível”.

A atividade de interpretação desse texto encontra-se na página 16 e visa levar os alunos à reflexão sobre os elementos estruturais do texto, os efeitos de sentido percebidos na leitura e as características desse tipo de linguagem. Porém, na página 15, as autoras rompem com o proposto, ao inserir a seção Painel do texto, pois, entre as atividades de leitura e interpretação, elas trazem informações sobre a autora Eva Furnari, sobre a evolução do livro e algumas curiosidades sobre bibliotecas. Acreditamos que esta seção seja interessante por promover a ampliação do conhecimento acerca do tema proposto na unidade, no entanto, ela se encontra em um local inapropriado, visto que provoca a quebra do raciocínio por parte do aluno.

Também nesta unidade, nas páginas 19 e 20, na seção Momento do texto 2, as autoras trazem a capa de um livro, cuja linguagem é mista, a fim de não só continuar a abordagem sobre os diferentes tipos de linguagem, mas também de dar início às discussões sobre gêneros textuais. Aqui, novamente nos deparamos com a fragmentação do trabalho textual, pois, ao finalizar o estudo do primeiro texto, em que se inicia a abordagem sobre os tipos de linguagem, as autoras entram com a seção Ampliação de vocabulário, introduzindo o conceito de vocábulo geral e, consequentemente, interrompendo a sequência do estudo sobre os diferentes tipos de linguagem. 
Observamos também que, no Momento do texto 2, as autoras apresentam a primeira e a quarta capa de um livro, com o objetivo de capacitar os alunos a usar as informações presentes no exterior da obra, que levam o leitor a decidir pela realização ou não da leitura.

O que nos chama a atenção é que as autoras separam primeira e quarta capa de um livro como pertencentes a gêneros textuais diferentes. Entendemos que essa divisão tem como critérios as características funcionais e organizacionais de cada uma das capas, ou seja, o plano composicional e o estilo.

No entanto, acreditamos que a capa de um livro não deva ser vista como algo desmembrado, mas sim como um todo significativo e, portanto, como um único gênero textual. Afinal, Bakhtin (apud Koch, 2006, p. 54) caracteriza gênero como tipos que, além de possuírem uma forma de composição própria e atenderem a vontade enunciativa do locutor, “[...] distinguem-se pelo conteúdo temático e pelo estilo [...]”, o que não é visto na classificação feita pelas autoras, pois elas, ao categorizarem as capas de um mesmo livro como pertencentes a gêneros diferentes, não consideram que tanto o conteúdo temático quanto a vontade do locutor não se alteram.

Ainda na unidade 01, na seção Questões textuais, que aborda novamente a teoria de gêneros textuais, as autoras propõem uma reflexão sobre a diversidade de gêneros encontrados em nosso dia a dia, tais como: rótulo de embalagem, poema, piada etc. Trabalho este bastante adequado ao $6^{\circ}$ ano, pois se seleciona para esta faixa etária o que Bakhtin (apud Koch, 2006, p. 54) distingue como gênero primário, ou seja, aqueles que “[...] são constituídos em situações de comunicação ligadas a esferas sociais cotidianas de relação humana [...]”, diferentemente do que denomina de gêneros secundários, visto que estes estão relacionados a esferas de interação social públicas e mais complexas. Sendo assim, a partir da observação desses gêneros comuns no cotidiano dos alunos, elas promovem uma discussão sobre quem é o autor, com que finalidade ele escreve o texto e a quem esse texto se destina.

Novamente, o problema encontrado está no local onde essa seção é posta, pois ela está entre as atividades de produção oral e escrita, acarretando a descontinuidade tanto na abordagem dos gêneros textuais, quanto no trabalho de reflexão sobre a produção textual.

Retomando o Momento do texto 2, cabe acrescentar que, na atividade de interpretação, há uma subdivisão denominada $O$ diálogo entre textos, página 21, em que as autoras ressaltam que não há texto puro, mas sim “[...] uma relação entre um texto e outro, ou seja, os textos 'dialogam' entre si”. Isso nos remete ao conceito de Intertextualidade que, segundo Koch (2000), define-se por sua natureza geral, quando há sobreposição de discursos, mesmo que não identificados, ou restrita, quando se torna explícita a relação de um texto com outros prévia e efetivamente produzidos.

Acreditamos que essa abordagem é relevante, porém pouco explorada, visto que as autoras se limitam à apresentação do conceito, mas não fazem o desdobramento do assunto em atividades práticas de escrita. 


\subsection{Negando: Português: dialogando com textos}

O livro Português: dialogando com textos apresenta-se em sete unidades, organizadas de modo homogêneo e subdivididas nas seções: Motivações, Descobertas, Reinvenção, Lendo mais, Papo-firme, Realimentação e Roda de Leitura.

Pretendendo motivar os alunos ao tema da unidade, as autoras trazem a seção Motivações, a fim de, segundo o Manual do professor (MARCONDES; PARISI, 2003, p. 15), “[...] propiciar situações de interação em sala de aula, reconhecendo a própria vivência do aluno e o conhecimento de diferentes universidades: o dos textos, o dos colegas, o do professor”.

Em seguida, apresentam a seção Descobertas, em que há um primeiro texto cuja função é motivar o aluno para o aprendizado do tópico gramatical em questão. Após as seções de estudo gramatical, apresentam-se outros textos, os quais se voltam, também, para o trabalho de leitura e compreensão.

A abordagem textual da seção Descobertas, segundo o Manual do professor (MARCONDES; PARISI, 2003, p. 16), procura “[...] explorar o gênero do texto, por meio de diferentes procedimentos, como a predição e a inferência a partir do título, que atuam como alavancas para a compreensão dos textos antes de eles serem lidos”. Entretanto, percebemos que o foco não está na questão de gêneros textuais, conforme afirmam as autoras, mas sim no conteúdo gramatical, abordado nas seções subsequentes. Logo, podemos dizer que o texto serve apenas como um pretexto para o desenrolar da unidade.

Além disso, ao apresentarem a obra no Manual do professor (MARCONDES; PARISI, 2003, p. 17), as autoras organizam uma tabela em que enumeram os textos escolhidos, justificam tais escolhas e classificam-nos em gêneros.

A classificação proposta revela uma certa confusão entre modalidades retóricas e gêneros textuais, pois, segundo Meurer (2000, p. 150), os gêneros são classificados a partir de suas características funcionais e organizacionais, adequadas a cada contexto, enquanto modalidades retóricas "[...] são estratégias utilizadas para organizar a linguagem [...]”, equivalentes ao que conhecemos por modalidade descritiva, narrativa e dissertativa. Logo, ao classificarem, por exemplo, o texto $O$ nome das vacas, de Vivina de Assis Viana, p. 14-16, como pertencente ao gênero narrativa intimista, as autoras acabam não diferenciando gêneros de modalidades.

Como, no decorrer da obra, são apresentados muitos textos narrativos, além do fato de não haver atividade que direcione o aluno a perceber a diferença entre os gêneros, acreditamos que não há possibilidade de se efetivar o aprendizado e o reconhecimento das particularidades de cada gênero, principal objetivo proposto pelas autoras, no que se refere às questões textuais. 


\subsection{Acertando: Língua portuguesa}

O livro Língua Portuguesa apresenta-se em quatorze capítulos, organizados de forma similares e subdivididos nas seções: Conversando, Texto e Partindo do texto, Pensando bem e Produzindo textos.

Buscando promover um diálogo com os alunos acerca dos temas a serem abordados e possibilitar, assim, ao professor, uma sondagem dos conhecimentos prévios dos alunos, os autores iniciam com a seção Conversando.

Em seguida, as seções Texto e Partindo do texto, norteadoras das temáticas desenvolvidas, apresentam, a cada capítulo, um gênero textual diferente, a fim de bem esclarecer a diversidade destes, além de abordar as funções textuais, levando, segundo do Manual do professor (VILLA-BÔAS; BORGES, 2006, p. 04), “[...] os leitores a perceberem o texto em seu processo amplo de significação (enunciação)”.

Após a seção Pensando bem, destinada aos aspectos gramaticais, os autores trazem a seção Produzindo textos, em que são propostas atividades que desenvolvam, conforme o Manual do professor (VILLA-BÔAS; BORGES, 2006, p. 4), “[...] habilidades de empregar mecanismos de produção de sentido capazes de expressar intencionalidade e de construir relações significativas dentro de diversas modalidades textuais”.

Percebemos que nesta obra o trabalho com gêneros textuais apresenta uma particularidade: é desenvolvido com objetivo de ensino-aprendizagem, ou seja, busca levar o aluno a conhecer para, em seguida, compreender os diferentes gêneros a partir de situações de comunicação que se aproximem da realidade. Textos estes que, ao serem inseridos no contexto sala de aula, passam pelo que Koch (2006, p. 58) chama de desdobramento, isso porque “[...] o gênero, ao funcionar em um lugar diferente daquele que está em sua origem, sofre necessariamente uma transformação, passando a gênero a aprender, ainda que permaneça gênero para comunicar”.

Além disso, notamos que há a preocupação, por parte dos autores, em envolverem os alunos no assunto apresentado, partindo, em todos os capítulos, de questionamentos acerca do gênero proposto, a fim de promover um ambiente mais propício à atividade subsequente, de produção textual, como podemos ver na página 8 , em que promovem, principalmente, uma reflexão sobre as características e o nome próprio de cada um, para, em seguida, propor uma atividade escrita, estabelecendo comparações entre o registro prévio - oral - e o atual - escrito.

Além de acreditarmos na premissa de que saber produzir textos é saber produzir significados, visto que neles as partes se esclarecem reciprocamente, admiramos a sintonia que os autores procuraram estabelecer entre o contexto e o texto, afinal, segundo Jackobson (apud KOCH, 2006, p. 67), “[...] a mensagem requer um contexto ao qual remete”. 


\section{CONSIDERAÇÕES FINAIS}

Historicamente, no Brasil, foi a partir da década de 50, segundo Soares (2000), que o ensino de Língua Portuguesa sofreu mudanças que vão desde alterações em sua nomenclatura até o recrutamento seletivo de professores, devido ao aumento do alunado - resultado do direito à escolarização.

Nesse contexto, o livro didático ganhou um espaço importante na sala de aula, pois, além de propor uma linha de trabalho e uma metodologia de ensino, serve de suporte ao desenvolvimento da proposta pedagógica.

Pesquisas anteriores sobre o livro didático sugerem que a maioria deles tem sido elaborada sob o enfoque tradicional, voltado quase que exclusivamente às classificações morfológico-sintáticas e ao trabalho descontextualizado de textos.

Tendo isso como pressuposto, poderia ser esperado tal resultado na análise proposta neste estudo.

No entanto, acreditando que os livros selecionados pudessem estar compatíveis com os PCNs, a análise aqui feita buscou fundamentar-se nas competências textuais, verificando como o material poderia possibilitar ao aluno o contato com diversos gêneros textuais e a reflexão da língua por meio da interação.

A análise do livro Linguagem: criação e interação mostrou-nos uma proposta bastante interessante de trabalho textual, apesar de alguns equívocos, como o desmembramento das capas de um livro em diferentes gêneros textuais e a má ordenação de páginas.

O livro Português: dialogando com textos deixou a desejar, apenas, nas questões de gêneros textuais, visto que não dá conta dos vários gêneros aos quais as autoras se propõem a abordar e, ainda, elas cometem um engano ao classificar como gênero as modalidades retóricas.

A última obra analisada, Língua portuguesa é, dos livros escolhidos para este estudo, a que melhor trabalha com gêneros textuais, visto que traz, além de uma seleção de textos adequada à faixa etária dos alunos, atividades encadeadas de modo que promove a associação direta com as várias realidades, ou seja, insere os textos em seus diferentes contextos, facilitando, assim, o aprendizado por parte do aluno.

Observando os materiais de análise, percebemos, nas atividades de leitura e produção textual, uma certa preocupação em apresentar aos alunos concepções em torno do texto, em consonância com a Proposta Curricular Nacional para o ensino de Língua Portuguesa, que estabelece, como um dos pressupostos, fornecer aos alunos condições efetivas de produção e recepção de textos.

Cabe ainda ressaltar que a segunda e a terceira obra analisadas, Português: dialogando com textos e Língua portuguesa, respectivamente, estruturam-se de modo bastante divergentes, o que pode trazer problemas à prática pedagógica em sala de aula, caso a escolha do livro didático não seja adequada à metodologia utilizada pela instituição e ao próprio objetivo da disciplina. 
Quanto aos autores, observamos que esta análise não busca ser limitadora, julgando a viabilidade do material, mas sim discutir a importância da escolha adequada à linha pedagógica da escola e, especialmente, ao que se acredita como ideal para os estudos de língua e linguagem.

Logo, é importante que os professores percebam que esse é um material que não se esgota em si mesmo, ou seja, ele não só serve como norteador, como também é um recurso que deve ser estendido à medida que o professor crítico, atento ao perfil da turma e à proposta da escola, julgue necessário. Enfim, o livro didático deve servir de subsídio não só para o professor, mas também ao aluno, visto que ele deve promover o desenvolvimento das competências textuais e gramaticais para este e pedagógicas para aquele.

Finalizando, esta pesquisa não se esgota neste trabalho, pois, além de ser um tema pouco estudado, aqui apresentamos apenas um recorte da realidade, não podendo estes resultados ser utilizados como regra a outros materiais.

\section{REFERÊNCIAS}

BENTES, Ana Cristina. Lingüística Textual. In: Introdução à lingüística: domínios e fronteiras. 2. ed. - São Paulo: Cortez, 2001, p-245-285.

BRANDÃO, Helena H. Nagamine. Introdução à Análise do Discurso. 5. ed. Campinas: UNICAMP, 1996.

BRASIL. Secretaria de Educação Fundamental. Parâmetros Curriculares Nacionais de Língua Portuguesa. Brasília: MEC/SEF, 1997.

FÁVERO, Leonor Lopes; KOCH, Ingedore Villaça. Linguística textual: introdução. São Paulo: Cortez, 1988.

KOCH, Ingedore Villaça. O texto e a construção dos sentidos. 4. ed. - São Paulo: Contexto, 2000.

KOCH, Ingedore Villaça. A inter-ação pela linguagem. São Paulo: Contexto, 2006. MARCONDES, Beatriz e PARISI, Paula. Português: dialogando com textos. Belo Horizonte: Formato, 2003.

MARCUSCHI, Luiz Antonio e KOCH, Ingedore Villaça. Processos de referenciação na produção discursiva. DELTA - Revista de Documentação de Estudos em Linguística Teórica e Aplicada. v. 14, n. especial. São Paulo, 1998, p. 169-190.

MARCUSCHI, Luiz Antonio. Estratégias de referenciação e progressão referencial na língua falada. In: ABAURRE, Maria Bernadete; RODRIGUES, Ângela (orgs.). Gramática do português falado. v. VIII. Campinas: UNICAMP, 2003. 
MEURER, José Luiz. O conhecimento de gêneros textuais e a formação do profissional da linguagem. In: Aspectos da lingüística aplicada. Florianópolis: Insular, 2000, p. 149-166.

SOARES, Magda. Português na escola: história de uma disciplina curricular. In Bagno, Marcos (org.) Lingüística da norma. São Paulo: Loyola, p. 155-177, 2000.

SOUZA, Cassia Leslie Garcia de e CAVÉQUIA, Marcia Paganini. Linguagem: criação e interação. São Paulo: Saraiva, 2005.

TRAVAGLIA, Luiz Carlos. Gramática e interação: uma proposta para o ensino da gramática no $1^{\circ}$ e $2^{\circ}$ graus. 8. ed. - São Paulo: Cortez, 2002.

VILLA-BÔAS, Juliana e BORGES, Juliana Faria. Língua portuguesa. São Paulo: IBEP, 2006. 